\section{"Jest taka cierpienia granica, za którą się uśmiech pogodny zaczyna". O kilku przedziwnych splotach poezji i rzeczywistości}

Adam Fitas

TEKSTY DRUGIE 2020, NR 6, S. 309-320

DOI: 10.18318/td.2020.6.18 | ORCID: 0000-0002-2523-0924

Panu Profesorowi Stefanowi Sawickiemuzwdzięcznościa

C zy są dziś jeszcze ludzie, którzy czerpią wiedzę z poezji i uczą się za jej pośrednictwem, jak żyć? Dla których między literaturą a rzeczywistością nie ma widocznych granic, wręcz przeciwnie, sfery lekturowa i egzystencjalna zdają się przenikać ze sobą, a nawet splatać w nierozerwalnym uścisku? Czy w naszych tak mocno wyspecjalizowanych czasach bywają czytelnicy, dla których wiersz to prawdziwy ekstrakt poznania, choć czasami trzeba do niego dojrzewać latami, a niejednokrotnie nie dorośnie się i przez całe życie? Czy zdarzają się nadal sytuacje, w których jak na dłoni, jasno i oczywiście, widać niezwykłe i tajemnicze związki między tekstem literackim a realnym życiem nie tylko autora, ale i odbiorców jego dzieł?

Te pytania i wiele innych, na pierwszy rzut oka tylko naiwnych, zadawałem sobie, czytając bibliofilsko wydaną krótką historię jednego utworu poetyckiego oraz
Adam Fitas - prof., pracuje w Katedrze Teorii i Antropologii Literatury KUL. Zainteresowania: twórczość Józefa Mackiewicza, Karola Ludwika Konińskiego, genologia polskiej prozy współczesnej, a zwłaszcza problematyka literatury dokumentu osobistego. Ostatnio opublikował książkę

Tylko prawda jest ciekawa. O twórczości Józefa Mackiewicza (Kraków-Warszawa 2019) i zredagował tom zbiorowy Koło Polonistów Studentów KUL (1919-2019). Szkice. Wspomnienia. Materiały (Lublin 2020). 
konkretnej i zajmującej jego recepcji1. Jeśli ktoś poszukiwałby ilustracji starożytnej maksymy Habent sua fata libelli, przykład jest pierwszorzędny. Należałoby może tylko sentencję jeszcze bardziej ukonkretnić: nie książki mają swe historie, ale pojedyncze wiersze, a nawet - jak pokazuje publikacja jednostkowe frazy. Naturalnie wszystko to wiemy od dawna, a jednak casus, który chcę przybliżyć, jest naprawdę wyjątkowy i - w moim przekonaniu wart szerszej reklamy. Słusznie też pomysłodawca i redaktor całości, Adam Cedro, pisze na końcu wprowadzenia, że „ta opowieść nie jest zestawiona wyłącznie dla miłoszologów”. I dodaje: „Myślę, że warto ją zrekonstruować i ocalić". Z perspektywy już czytelnika dorzucę - naprawdę warto.

Opowieść nie ma spisu treści, ale „układ zdarzeń”, są to bowiem w istocie prawdziwe sytuacje liryczne wprowadzające kolejne podmioty w polifonicznym dramacie. Dramacie i w sensie rodzajowym, ponieważ głosy te wchodzą ze sobą w interesujący dialog, i w sensie potocznym, gdyż od początku obcujemy tutaj z cierpieniem, bólem i śmiercią. Da się też odnaleźć w tych pozornych tylko zbiegach okoliczności poszczególne akty czy sceny, a także zawiązanie akcji, punkt kulminacyjny czy wydłużony epilog zdarzeń.

Historia ma troje głównych bohaterów: poetę i dwie literaturoznawczynie Wszyscy już nie żyją, a jednak dzięki tej małej książeczce, ozdobionej skrupulatnie dobranymi fotografiami i toczącej się w rytmie sugestywnie ułożonych wypadków, zaczynają egzystować bardzo zmysłowo i intensywnie.

O pierwszej osobie dramatu nie trzeba nic mówić, wystarczy podać imię i nazwisko: Czesław Miłosz.

Druga postać, choć znana, to przecież nie tak jak autor Doliny Issy, więc wymaga słowa dopowiedzenia: Danuta Zamącińska (po mężu Paluchowska, ale będziemy tu używać jej panieńskiego nazwiska, którym podpisywała swoje prace badawcze) - historyk literatury romantycznej, na polonistyce KUL obecna ponad pół wieku, od studiów rozpoczętych na początku lat 50. XX wieku (1952) do swojej śmierci w 2007 roku. Subtelna i wnikliwa interpretatorka poezji Mickiewicza, Słowackiego, Norwida czy Przybosia, świetny nauczyciel akademicki. Najlepszą rekomendację wystawił jej przed laty Zdzisław Łapiński, który, recenzując rozprawkę autorki wypełnioną niekonwencjonalnymi interpretacjami wierszy wspomnianych poetów romantycznych, tak oto kończył wywód:

1 Cz. Miłosz, D. Paluchowska, K. Papierkowska Walc na troje, Pewne Wydawnictwo, Kielce 2019. W dalszych cytatach z książki będę stosował skrót W, po którym cyframi arabskimi podany zostanie numer strony. 
jeśli gdzieś w „Pamiętniku Literackim” czy „Rocznikach Humanistycznych" trafimy na nieznane pióro, które w sposób spokojny, lecz stanowczy wypowiada się wbrew utartym poglądom i uznanym autorytetom, jeśli zabłyśnie ono elegancją stylu, maskowaną ironią, jeśli świadczyć będzie o rzeczowym, a zarazem zasadniczym stosunku do literatury i o nieskazitelnym warsztacie badawczym - jest duże prawdopodobieństwo, że będzie to studentka, która swoje ćwieczenia odbywała pod okiem Danuty Zamącińskiej. Osobiście bardzo żałuję, że nie mogę być studentką Zamącińskiej. Na pociechę pozostają mi Stynne - nieznane. Jakże nieznośna i jakże czarująca książeczka!²

Trzecia bohaterka dramatu wymaga najwięcej komentarza, bo nie zdążyła rozwinąć skrzydeł, które dopiero gotowały się do lotu. Krystyna Papierkowska, studentka polonistyki KUL (1953-1958) i bliska koleżanka Zamącińskiej z roku, prezes znakomitego w tamtych czasach Koła Polonistów tej uczelni (1956-1957), przedwcześnie zmarła na raka w 1960 roku, mając zaledwie 25 lat. Ta świetnie zapowiadająca się literaturoznawczyni była uczestniczką i laureatką Ogólnopolskich Zjazdów Polonistów w Warszawie (1956) i Toruniu (1958)3․ Oto jak charakteryzował ją jako człowieka i filologa jeden z jej

2 Z. Łapiński Nieznośna książeczka, "Tygodnik Powszechny” 1985 nr 37. Cyt. za: Poznawać (więc kochać!). O Danucie Paluchowskiej, red. A. Seweryn, D. Seweryn, Norbertinum, Lublin 2010, s. 188. Dorobek publikacyjny Danuty Zamącińskiej nie jest obfity, ale jej przykład pokazuje, jak paradoksalne są dzisiejsze oceny pracowników naukowych. Wystarczy przeczytać tę małą książeczkę wydaną w 1985 roku, a zatytułowaną Słynne - nieznane, czyli publikację, którą omawiał Łapiński, aby zdać sobie sprawę, że nie ilość, ale jakość jest decydująca w takiej czy innej kwalifikacji uczonego. Tytuł książki może być zresztą symptomatyczny dla całej spuścizny badawczej autorki, która wyspecjalizowała się w odkrywaniu tego, co wydaje się już poznane, a pod jej piórem sprawia wrażenie zaledwie dotkniętego, czekającego nie tyle na swojego badacza, ile na czujące i miłujące serce niespiesznego czytelnika. Zupełnie więc nieprzypadkowy, ale bardzo trafny tytuł nadali jej uczniowie w książce wspomnieniowej: Poznawać (więc kochać!).

3 Bibliografia prac Papierkowskiej z wiadomych względów nie może być długa. Wszystkie one, jak studium o Walcu Miłosza, mają charakter studencki, choć już dojrzały: zapowiadają badaczkę niezależną, ale umiejącą także doskonale współpracować w zespole. Na VII Zjeździe Kół Polonistycznych w Warszawie w 1956 roku zaprezentowała wraz z Anną Chruszczewską (później Opacką) i Ireneuszem Opackim pracę Pokrewieństwo i artyzm. (Uwagi o liryce rzymsko-drezdeńskiej). W 1958 roku na spotkaniu w Toruniu (VIII Zjazd) zdobyła III nagrodę za rozprawę Postawa badawcza Wacława Borowego. (Próba charakterystyki). Obydwie prace przedrukowane zostały w dwumiesięczniku Koła Polonistów Studentów KUL "Polonista” (1960 nr 12: listopad-grudzień). Na marginesie: od wielu lat zastanawiam się, dlaczego dziś nie odbywają się takie zjazdy, na których ostrzyła przed laty pióra młoda brać polonistyczna pod wprawnym okiem swoich mistrzów uniwersyteckich. Krzywym odbiciem w porównaniu z tą tradycją wydaje 
mistrzów i wieloletni kurator Koła Polonistów Studentów KUL Czesław Zgorzelski:

W pamięci naszej pozostanie jako uosobienie serdeczności i bezpośredniej, radosnej pogody. Taką widywaliśmy ją w salach wykładowych, w kręgu koleżeńskim, w każdym zetknięciu codziennego życia uniwersyteckiego. Zdawało się: niewyczerpane są źródła radości, promiennego spojrzenia i jasnego uśmiechu przyjaźni, którym zjednywać umiała sobie tylu przyjaciół. Ujmowała otoczenie czujną wrażliwością swych uczuć i szczerym, spontanicznym charakterem ich wyrazu.

Ale pamiętamy także inną Krysię. W czasie ćwiczeń, na seminariach, w dyskusjach, na zebraniach studenckich przychodziły chwile skupienia, poważnego namysłu, sceptycznej rozwagi. I wówczas w tym, co mówiła, padały zazwyczaj słowa trafnego krytycyzmu, uwagi poddane rygorom myśli, świadczące o poczuciu odpowiedzialności za wyrażone przekonania, zdania nieufności wobec pojęć mgliście precyzowanych, wobec sądów niedostatecznie umotywowanych, wobec ujęć błyskotliwych, efektownych, a w istocie - trudno sprawdzalnych. ${ }^{4}$

Akcja dramatu zaczyna się w 1955 roku, kiedy to młoda i dobrze zapowiadająca się studentka polonistyki przygotowuje w ramach ćwiczeń z poetyki prowadzonych przez Stefana Sawickiego, wówczas magistra, pracę poświęconą analizie wiersza Czesława Miłosza Walc, pochodzącego ze słynnego tomu Ocalenie. Jednak przedakcja zdarzeń musi być datowana dużo wcześniej: rzecz zaczyna się w Warszawie w 1942 roku, kiedy to - jak wiemy z podpisu pod tekstem - utwór powstał. A nawet jeszcze wcześniej: najdawniejszym początkiem jest bowiem akcja liryczna wiersza, w której sceny sprzed kataklizmów pierwszej połowy XX wieku (a dokładniej z 1910 roku) sąsiadują z wizją apokalipsy spełnionej w rzeczywistości II wojny światowej, z jej cierpieniami, śmiercią i obozami zagłady. Papierkowska dostrzega dwudzielną strukturę liryku oraz snuje ciekawe refleksje na temat głównych bohaterów wiersza: kobiety tańczącej walca na sali balowej u schyłku La belle épouqe oraz jej syna, którego tragiczna przyszłość odsłonięta zostaje matce podczas zabawy w metaforycznym widzeniu.

mi się wiele dzisiejszych konferencji. Wygłasza się bowiem często na nich referaty, które ze względów merytorycznych w ogóle nie zostałyby zakwalifikowane do uczestnictwa w tego typu zjazdach w latach 50. czy 60. ubiegłego wieku. 
Zawiązanie akcji to jednak w przypadku Walca na troje przede wszystkim nomen omen - spotkanie, a właściwie splot między bohaterami wiersza, jego autorem i czytelniczką. Rozprawka była na tyle dobra, że nie tylko odsłaniała badawczy potencjał adeptki polonistyki, ale miała także charakter odkrywczy wobec samego utworu. Uwagi Papierkowskiej, zwłaszcza te o strukturze wiersza i jego wersyfikacji, przetrwały długą próbę czasu - po latach jej spostrzeżenia w dużej mierze potwierdziła oraz znacząco pogłębiła i rozwinęła Zdzisława Kopczyńska w swej znakomitej analizie $W_{a l c a^{5}}$. Niemniej jednak niektórzy poloniści na KUL do dziś czytają pracę Papierkowskiej podczas ćwiczeń z poetyki na I roku. Z jednej strony dlatego, że jest ona bliższa ich amatorskiemu jeszcze spojrzeniu, z drugiej strony także z innych względów, o których szerzej powiem za chwilę. W każdym razie wspomniana rozprawka, a właściwie spotkanie młodej badaczki i wiersza, to swoiste zdarzenie dramatyczne, jakby rzecz ujęła Irena Sławińska, zdarzenie, które będzie miało konsekwencje w latach następnych, skrupulatnie rekonstruowanych w Walcu na troje. Innymi słowy, tworzy się w ten sposób nowa, wykraczająca poza wiersz sytuacja liryczna, której dalsze ciągi będą towarzyszyły nam odtąd w lekturze książki.

Niewątpliwie był to ten moment, kiedy osobista wrażliwość i charakter filologa spotykają się w sposób prosty i głęboki z poetycką materią tekstu. Papierkowska już na początku analizy Walca dostrzega w nim „liryzm pojęty jako uczucie przepajające utwór i udzielające się czytelnikowi oraz subiektywizm przejawiający się w stosunku poety do przedstawionych rzeczy" (W15). I liryzm, i subiektywizm są tu wyraźnymi pośrednikami między poezją a rzeczywistością, między historią opisaną w wierszu, samym utworem i życiem czytelniczki. I jedno, i drugie, i trzecie kryją jednak w sobie potencjał znaczeniowy, który dopiero na nas czeka i będzie stopniowo odkrywany w kolejnych scenach czy aktach dramatu.

Po lekturze wiersza i jego analizie obcujemy z kilkoma zdjęciami młodej badaczki. Twarz pełna rzeczywiście promiennego uśmiechu, o którym wspominał Zgorzelski, wesoła i pogodna, choć kolejne fotografie - jak można się domyślić - pochodzą z okresu choroby Papierkowskiej. Bohaterka leży w łóżku - najpierw obok rodziców, potem w dużym zbliżeniu, z głową na poduszce. Uśmiech jednak wciąż nie schodzi jej z twarzy, jakby cierpienie i śmierć nie miały do niej przystępu albo jakby nie budziły żadnego niepokoju czy trwogi.

5 Zob. Z. Kopczyńska O wersyfikacji „,Walca” Czesława Miłosza , Pamiętnik Literacki” 1981 z. 4. 
Kolejna stronica zawiera konwencjonalny nekrolog młodej polonistki, zamieszczony w „Zeszytach Naukowych KUL” z 1961 roku, który koresponduje z umieszczonym po przeciwnej stronie zdjęciem nagrobka zmarłej. Pomnika pięknego, przypominającego zamkniętą księgę, z krzyżem pośrodku, nazwiskiem zmarłej, datą jej urodzenia i śmierci (13 grudnia 1935 - 3 listopada 1960). Na krawędziach księgi, niczym ornament biegnący od lewej strony ku górze, a następnie w prawo i w dół napis, widnieje cytat z Walca Miłosza: "Rozumiesz. Jest taka cierpienia granica, / Za którą się uśmiech pogodny zaczyna". Już konstatacja samego sygnalizowanego tu splotu historii z wiersza i życia młodej badaczki skłania do refleksji nad przenikaniem się poetyckich i realnych historii. Zaczęło się od życia sportretowanego przez Miłosza w tekście, a skończyło na biografii wrażliwej czytelniczki. Poezja dostrzeżona w rzeczywistości przez autora Trzech zim stała się poezją ucieleśnioną w młodym i intensywnie przeżywanym życiu, a następnie przybrała postać symboliczną dzięki pomysłodawcom nagrobka polonistki. Ale historia na tym się nie kończy, jesteśmy dopiero w jej połowie, choć punkt kulminacyjny mamy już właściwie za sobą. Pozwala on skonstatować wyraźnie, że prawdziwa poezja swobodnie przekracza jedną rzeczywistość i wkracza do następnej, a nawet więcej - że poezja w przedziwny sposób zostawia ślady nie tylko na bohaterach, których wprost przywołuje z odmętów historii, ale odciska też znamienne piętno na jej niektórych czytelnikach i badaczach.

Zawiązana w lekturze wiersza i przy pisaniu studium więź Papierkowskiej z Miłoszem nie kończy się więc wraz ze śmiercią młodej polonistki, ale przybiera postać kilkuczęściowego epilogu. Do akcji wkracza jej koleżanka ze studiów, którą łączyły z Krystyną i autentyczna przyjaźń, i pasje literackie, i nawet wspólna publikacja. Nie została ona (i słusznie) zamieszczona w omawianej książeczce, ale można ją odnaleźć wśród wspomnień o Danucie Zamącińskiej-Paluchowskiej oraz pośród jej zapoznanych tekstów, wydanych w przywoływanej już przeze mnie książce ${ }^{6}$. Wróćmy jednak do Walca na troje. W kolejnym jego akcie (czy tanecznym zwrocie), kilka miesięcy po śmierci przyjaciółki, na wiosnę 1961 roku, rówieśniczka zmarłej wysyła do Czesława Miłosza (przebywającego wówczas w Berkeley) list z analizą Walca pióra Papierkowskiej. Niestety, tego listu także zabrakło w publikacji, z załączonej odpowiedzi Miłosza domyślać się jednak możemy, że były w nim konkretne

6 K. Papierkowska, D. Zamącińska O Juliuszu Słowackim 1809-1959, "Zeszyty Naukowe KUL” 1959 z. 2, s. 125-127. Jest to recenzja tomu „Roczników Humanistycznych" poświęconego twórczości Juliusza Słowackiego (1959 t. VIII z. 1). Przedruk w tomie Poznawać (więc kochać!). 
informacje o chorobie i śmierci polonistki oraz prośba Zamącińskiej o rzucenie światła na niektóre wątpliwości interpretacyjne.

Odpowiedź autora Trzech zim datowana jest na 27 lipca 1961 roku - Walc na troje zawiera i reprodukcję autografu listu, i jego wersję drukowaną. Jest to gratka nie tylko dla miłoszologów, ale także dla literaturoznawców oraz dla wszystkich czytelników poezji. Pierwsi będą umieli najlepiej ocenić wartość dokumentu i umieścić go w porządku fizycznej i duchowej biografii Miłosza, drugich zainteresuje zapewne zwłaszcza ten fragment odpowiedzi przyszłego noblisty, w którym odnosi się on do odkrytych przez młodą badaczkę aspektów budowy wersyfikacyjnej wiersza. Niejednego zaskoczy, a niektórych może i zastanowi bezceremonialność takiego oto wyznania: „Analizę metryczną czytałem, jakby chodziło o czyjś obcy utwór, co prawda nigdy się nad jego wersyfikacją nie zastanawiałem - sam temat czy sytuacja narzuca zwykle środki". A przypomnieć trzeba, że wiersz ten ma wyjątkowo misterną i przemyślaną konstrukcję wersyfikacyjną. Gdyby dać wiarę Miłoszowi, osoba artysty zyskuje aureolę niezwykłej i wyjątkowej tajemnicy, jeśli zaś jego wyznanie zakwestionujemy, odsłoni się inna postać poety, niekoniecznie pokornego, ale za to starannie ukrywającego tajniki procesu tworzenia. Arkana twórczości, ale już w innym aspekcie, zainteresują zapewne i miłoszologów, i polonistów, i zwykłych czytelników. Miłosz zdradza bowiem w przesłanej korespondencji pierwowzory bohaterów wiersza oraz rozmyśla nad możliwym przecięciem się ich losów z życiem młodej polonistki. Oto najważniejszy dla tego aktu dramatu fragment listu:

Kobietę, która występuje jako tancerka, poznałem w dzieciństwie. Podziwiałem ją, była wtedy panną niezwykłej urody. Jej twarz niekiedy wyziera z książek o polskim malarstwie, bo był to jeden z najlepszych portretów znanego kiedyś malarza, Janowskiego. Osoba ta nadal żyje i mieszka w Polsce - Krystyna, nie wiedząc o tym, mogła się była kiedyś z nią spotkać. Jedyny syn tej kobiety, w latach II wojny światowej b. młody chłopak, umarł w hitlerowskim obozie koncentracyjnym. Ale teraz włącza się w ten zespół konkretnych ludzi jeszcze jedna postać, Pani Przyjaciółka. Tamtych wciąż widzę, jej nie widzę i nie bardzo umiem ją sobie wyobrazić. Jeżeli Pani to nie sprawi dużej fatygi, wdzięczny byłbym za małą fotografię Krystyny i trochę szczegółów biograficznych. Wszystko to razem komponuje się w pewną całość. Nie mam pociągu do tzw. beletrystyki i nie chodzi mi wcale o kompozycję w sensie estetycznym, ale raczej filozoficznym, o realność (jedyną i stałą realność) nieszczęścia, 
które dosięga albo jako obóz śmierci, albo jako nieuleczalna choroba (W 32-33).

Biorąc pod uwagę te fakty, Miłosz określa swój utwór jako „przeraźliwie realistyczny". Nie znam całej literatury przedmiotu poświęconej autorowi Trzech zim, nie dam więc głowy, że ktoś nie odkrył tego wcześniej, ale zadałem sobie nieco trudu, aby te realia jeszcze bardziej przybliżyć. Otóż malarz Janowski, o którym wspomina poeta, to Ludomir Janowski (1862-1939), znany głównie ze swoich portretów. Natomiast kobieta widniejąca na jego obrazie, a jednocześnie główna bohaterka Walca, to najpewniej ciotka Czesława Miłosza, Gabriela Lipska z domu Kunat, mieszkająca w majątku Krasnogruda na Suwalszczyźnie, gdzie Miłosz często gościł jako młodzieniec w latach 20.i 30.7

Dowody na prawdziwość tej hipotezy są dość mocne. Po pierwsze, jedyny obraz Ludomira Janowskiego zamieszczony w kilkukrotnie wznawianym od początku XX wieku wydawnictwie Album malarstwa polskiego. Album d'lart polonaise to portret, który w konfrontacji z fotografią Gabrieli Kunat nie pozostawia większych wątpliwości co do tożsamości kobiety na obrazie $e^{8}$. Po drugie, jak dowiadujemy się z losów ciotki Miłosza, w czasie II wojny światowej dwór w Krasnogrudzie służył jako punkt przerzutowy polskich oficerów na zachód (przez Łotwę i Szwecję do Anglii). Niemcy, którzy wpadli na trop tego procederu, nie tylko odebrali majątek właścicielom, ale aresztowali także męża Gabrieli, Władysława Lipskiego, oraz ich piętnastoletniego syna Zygmunta. Zostali oni osadzeni w obozie w Sachsenhausen, gdzie młody

7 Biografista poety sugeruje nawet, że odegrała ona rolę nie tylko platonicznego, ale i fizycznego pierwszego wtajemniczenia Miłosza w świat erotyzmu. Zob. A. Franaszek Miłosz. Biografia, Znak, Kraków 2011, s. 91. Na s. 85 pisze zaś o niej: „Piękna i refleksyjna Ela [tak wśród bliskich nazywana była Gabriela], uwieczniona na fotografiach i portrecie pędzla Ludomira Janowskiego, ściągająca spojrzenia wszystkich mężczyzn gwiazdka wileńskiego amatorskiego kabaretu «Ach»".

Korzystałem z wersji elektronicznej albumu dostępnej pod adresem: http://kpbc.umk.pl/dlibra/docmetadata?id=40026\&from=pubindex \&dirids=91\&lp=5 (dostęp: 26 sierpnia 2019). Już po napisaniu tego tekstu, w trakcie jego korekty, trafiłem - dzięki wnikliwości jednej z moich studentek, Pauliny Borowej - na jeszcze inny portret pędzla Ludomira Janowskiego, który ze względu na swój tytuł (Portret P-ny K.) i silniejsze podobieństwo namalowanej postaci do zdjęcia Gabrieli Kunat zamieszczonego na stronie internetowej poety (h t t p s: // w w w . m i l o s z.pl, dostęp 11 grudnia 2020) - wydaje się lepszym tropem. Zob. https://polona.pl/item/ malarstwo-polskie-w-odbitkach-barwnych-1-48-odbitek-48-tekstow,MTA4ODI4/49/\#info:m etadata (dostęp: 11 grudnia 2020). 
chłopak, oddzielony od ojca i zapędzony do ciężkiej pracy, zmarł z wycieńczenia i głodu'. Po trzecie, Gabriela Lipska zmarła w 1962 roku, czyli w czasie, gdy Miłosz pisał list do Zamącińskiej, żyła jeszcze i istotnie jej drogi mogły skrzyżować się ze ścieżkami Krystyny Papierkowskiej.

Tyle na temat "przeraźliwej realistyczności” wiersza. Co prawda nie ona interesuje nas tu najbardziej, ale warto uświadomić sobie jeszcze raz silne zakorzenienie wierszy Miłosza (które w tym aspekcie są często utworami „z kluczem” biograficznym) w realnej rzeczywistości. Walc na troje rozwija przed nami dalszy fascynujący epilog spotkania badaczki i wiersza. Po liście poety znalazł się tu więc szkic odpowiedzi Zamącińskiej z 1962 roku. Zaczyna ją ona w sposób symptomatyczny: „przed paroma tygodniami - drogą okrężną - wysłałam materiały związane z Krysią Papierkowską - dobrą czytelniczką Walca". Dziś już trudno byłoby pewnie komuś od razu zrozumieć to wprowadzenie, ale czytelnikom mającym w pamięci PRL „droga okrężna” od razu kojarzyć się będzie z ścieżką korespondencji omijającą oficjalną cenzurę, na którą wymiana listów z kimś takim jak poeta emigracyjny (w dodatku z życiorysem takim jak Miłosz) w tamtych latach była szczególnie narażona. W imieniu własnym i przyjaciół z polonistyki Zamącińska tak odnosi się do informacji związanych z genezą Walca:

dla nas wciąż [jest] najważniejsza w utworze lirycznym nie jego "przeraźliwa realistyczność”, ale „filozoficzna ogólność”, pozwalająca wielu ludziom czytać utwór definicją własnego losu - bo Walc zawiera tę sumę piękna, cierpienia i tajemnicy, która jest udziałem każdego człowieka (czy prawie każdego). I tak matka Krysi, która żyje, też kiedyś „tańczyła”, ale żaden głos nie śmiał uchylić zasłony jej przyszłego bólu - śmierci córki (W 34).

Ale poza tymi refleksjami na temat rozumienia i wartości poezji przyszła badaczka romantyzmu dzieli się też własnymi doświadczeniami związanymi z przyjaźnią z Papierkowską. Padają tu słowa, że prawdziwej istoty jej osobowości nie da się oddać w żadnym wspomnieniu ani za pomocą żadnej fotografii - „to wszystko jest mniejsze, mniej wyraziste, niż był np. ruch Jej ręki uniesionej znad kołdry na powitanie" (W 34). Pojawia się tu niezwykła

9 Zob. informacje na ten temat w serwisie internetowym Krystyny i Jerzego Samusików poświęconym polskim siedzibom szlacheckim na Podlasiu i pograniczu polsko-białorusko-litewskim: http://dworypogranicza.pl/index.php/dwory/8-krasnogruda (dostęp: 26 sierpnia 2019). 
- niemal jak u poety - wrażliwość na konkret, ale i świadomość, że słowo jest bardzo ułomne wobec prawdziwej natury człowieka, której istotę wyraża wszakże czasem nawet jeden zwykły ruch czy gest. A potem następuje wyznanie autorki o wspólnych z Krystyną wtajemniczeniach zarazem w poezję i w życie:

Dużo przebywałyśmy razem i rozmawiałyśmy, może głównie właśnie o poezji - bo stąd czerpałyśmy wiedzę o wielu sprawach. Niejednokrotnie tomy Ocalenia i Światta dziennego [...] były przedmiotem i źródłem tego poznania - były też światem, w które wkraczało się, by przejść ponad chorobą; nigdy doprawdy nie widziałam chorowania - umierania tak estetycznego. Dla Niej poezja i religia, a dla mnie Ona, jej postawa heroiczna, pozwalała przedzierać się przez to, co nazywam „moim życiem” (W 34).

Jest jeszcze kartka pocztowa Miłosza z potwierdzeniem otrzymania zdjęć i materiałów. Jednak w tym przypadku ważna wydaje się z kolei nie tyle treść pocztówki, ile fotografia na jej odwrocie (reprodukowana w publikacji). Miłosz przesyła ją z Asyżu, a obraz przedstawia klasztor, gdzie była grota św. Franciszka, a dokładniej - „taki sam jak w 1440 roku” - refektarz. Skromna drewniana izba, ławy przy ścianie, flakon z bukietem kwiatów na jednej z nich oraz światło wpadające kilkoma snopami do ciemnego wnętrza. Poezja bez słów.

Ostatni tekst książeczki, po którym znajduje się zbiór kilku zdjęć zrobionych przez Adama Cedrę podczas pobytu Miłosza w Lublinie w czerwcu 1981 roku, rozciąga jeszcze bardziej i wzbogaca epilog całej tej „sprawy”. Jest to projekt wystąpienia Danuty Zamącińskiej na sesji poświęconej stosunkowi współczesnej literatury polskiej do romantyzmu, zorganizowanej w Kazimierzu Dolnym w październiku 2004 roku (kilka miesięcy po śmierci poety). Projekt ten zawiera przypomnienie przywołanej wyżej korespondencji z Miłoszem („moim Miłoszem”, jak zaznacza autorka), a kończy jeszcze jedno nawiązanie do Walca. Gdy czytałem je po raz pierwszy, wydało mi się trafne i zdradzające sposób myślenia subtelnej badaczki epoki Mickiewicza i Norwida. Jednak po zaglądnięciu w „przeraźliwą realistyczność” wiersza muszę powiedzieć, że Zamącińska się myliła. Albo raczej: była w błędzie i miała rację jednocześnie. Oddajmy jej jednak najpierw głos raz jeszcze:

Dopiero później zrozumiałam to przejmujące zafałszowanie: ,jedyny syn tej kobiety [...] umarł w hitlerowskim obozie koncentracyjnym". 
?

Czy Miłosz mógł liczyć wówczas, że młodej uczennicy jego wileńskich znajomych (prof. Zgorzelski, prof. Sławińska) prawdę, o jakie obozy w Walcu idzie, pomoże [pojąć] lektura Dziadów? Że „lodowe pola” i „błysk bata" to tam i tylko tam? ${ }^{10}$

Zabezpieczył swój list wysłany normalną pocztą przed okiem cenzora, dodając ów przymiotnik przez lat wiele towarzyszący desygnatowi „obóz”. "Obóz hitlerowski".

Jak wiele razy z eseistyką Miłosza nie mogę się pogodzić - to ten przygodny mój dokument poświadcza znakomitość Miłosza jako użytkownika tradycji romantycznej (W 39).

Wiemy już, że najprawdopodobniej nie doszło tu do maskowania przez Miłosza z powodów cenzuralnych wydarzeń opisanych w wierszu: w rzeczywistości osoba będąca pierwowzorem syna $\mathrm{z}$ utworu naprawdę zginęła w obozie niemieckim. Ale zaznaczyłem, że Zamącińska myliła się tylko częściowo. Zważywszy na to, co napisała o istocie poezji (nie „przeraźliwa realistyczność", ale „filozoficzna ogólność” jest w niej ważna), wskazana strofa Walca jest przecież nie tylko zapisem konkretnego doświadczenia, ale także, a może przede wszystkim, symbolem całej apokalipsy obozów wojennych, także tych fundowanych pod butem sowieckim i wszelkich innych.

Atoli nie tyle Miłosz, ile badaczka okazała się tu medium tradycji romantycznej. Nie ma już nic na ten temat w książeczce, do której lektury bardzo zachęcam, ale dopowiedzieć trzeba koniecznie, że na grobie rodzinnym prof. Zamącińskiej wyczytać można, że miejsce pochówku jej ojca nie jest znane, należał bowiem do tej części polskich wojskowych, których tragiczny los na Wschodzie pozostaje dotąd nieustalony, a miejsce stracenia - niewiadome ${ }^{11}$.

W ten sposób historia opowiedziana w Walcu na troje zatoczyła koło: wszystko zaczęło się od „przeraźliwej realistyczności” i na niej się skończyło, po drodze jednak mieliśmy kilka aktów epifanii poezji czystej. W jednej ze strof Walca, w której pojawia się syn bohaterki, słyszymy słowa kierowane do matki: „I nie wiesz, czy śpiewa tak walc, czy twój płacz”. Doprawdy, może ktoś weźmie mnie ponownie za bardzo naiwnego czytelnika, a te uwagi za

10 Zamącińska odwołuje się tu do motywów obrazowych z części wizyjnej Walca, w której pojawiają się między innymi "lodowe pola” i „błysk bata”.

11 Dokładny napis na grobie mówi: „Bolesławowi Zamącińskiemu 1893-1940 Ostaszków? Za pomnik grobowy". 
górnolotne wynurzenia, ale niejednokrotnie podczas lektury tej niewielkiej książeczki zdumiony byłem tajemnicą łączącą - niczym trwały stop - różne aspekty rzeczywistości i literatury. Łączącą do tego stopnia, że zacierały się granice realiów i poezji. Jedno cierpienie (i jego artystyczny emblemat) koresponduje tu z innym (i tegoż znakami), jedna konkretna i uogólniona śmierć z drugą (a nawet trzecią) i jej symbolami. Mieszają się też osoby dramatu: adresat wiersza i jego czytelniczki, poezja umiejscowiona w autorze i w jej odbiorcach. Słowem, prawdziwe koło hermeneutyczne obracające tajemnicę ludzkiego losu i splatające ze sobą wiersz i autentyczne doznania. Dla mnie Walc na troje to lektura obowiązkowa nie tylko dla każdego polonisty, ale także dla wszystkich miłośników literatury, zwłaszcza zaś dla niedowiarków i wątpiących w niezwykłą wartość sztuki słowa jako poznania par excellence.

\section{Abstract}

\section{Adam Fitas}

THE JOHN PAUL II CATHOLIC UNIVERSITY OF LUBLIN

"Pain Has a Limit and Then There Begins a Smile That Shows Bliss": An Unusual Entanglement of Poetry and Reality

Fitas explores the mysterious links between literature and reality that can arise when a sensitive reader encounters a poetic work. His starting point is the book Walc na troje [Waltz for Three], which presents literary texts, correspondence as well as manuscript drafts and photographs to showcase the unusual reception of one poem by Czesław Miłosz. This reception reveals an interesting entanglement between the lives of the poet, of his characters and of the readers of his poems on the one hand and, on the other hand, the existence of characters and meanings immortalised through poetic imagination in the literary text.

\section{Keywords}

Czesław Miłosz, Walc, Krystyna Papierkowska, Danuta Zamącińska, poetry and reality 